\title{
COVID-19 and biomass in Peru: Between need and risk
}

\section{COVID-19 y biomasa en Perú: Entre necesidad y riesgo}

Dear editor,

The use of biomass for domestic use is still a challenge for public health as it generates indoor contamination. Evidence indicates that rural residents with exposure to biomass are at increased risk of respiratory infections and chronic obstructive pulmonary disease (COPD) ${ }^{(1)}$. Worldwide, approximately 3 billion people do not have access to clean cooking fuels ${ }^{(2)}$. An example of this is India: $50 \%$ of households continue to use polluting solid fuels to meet their energy needs, including cooking ${ }^{(3)}$. In Peru, as of October 2017, 1 million 751 thousand 433 households used solid fuels for cooking $(21.2 \%$ of all registered households in the country), $70.1 \%$ in rural areas ${ }^{(4)}$. The use of this fuel in our country is currently a very worrying reality.

Furthermore, the COVID-19 quarantine affected household fuel use of 700 million in Sub-Saharan Africa: $27 \%$ of households that used primarily liquefied petroleum gas (LPG) for cooking before quarantine, switched to kerosene $(14 \%)$ or firewood $(13 \%)$, causing a probable increase in indoor pollution ${ }^{(5)}$. This situation has not been evaluated in our country, but it is a possibility, and it would be an interesting research topic.

In places such as Mexico ${ }^{(6)}$ and India ${ }^{(3)}$, exposure before biomass consumption has been associated with greater susceptibility to COVID-19 infection with greater morbidity and mortality. Other studies also support the link between biomass air pollution and COVID-19 ${ }^{(7,8)}$.

COPD due to biomass consumption (the most frequent in our country) is characteristic of women of small stature, obese, from rural areas, and with an interstitial lung pattern ${ }^{(9)}$. Characteristically it is underdiagnosed comorbidity and not considered by patients and health personnel. This could explain why it is not being considered in a different hospital and epidemiological studies in our country.

We should mention, for example, that, in a recent study in a hospital of the Ministry of Health in Piura-Peru, it has been found that of 391 patients with Moderate / severe COVID-19, 48 (17.7\%) reported previous and prolonged consumption of biomass, and 19(20\%) died (Data not yet published).

As measures with potential short-term impact would be the early and sensitive screening of questionnaires or forms of diagnosis of biomass consumption in patients with COVID-19 and the long term, support for the energy and sustainable conversion of rural households to the cooks with clean fuels ${ }^{(10)}$.

\section{BIBLIOGRAPHIC REFERENCES}

1. Conticini E, Frediani B, Caro D. Can atmospheric pollution be considered a co-factor in extremely high level of SARS-CoV-2 lethality in Northern Italy? Environ. Pollut. (2020), p.

\section{FILIATION}

1. Facultad de Medicina, Universidad Señor de Sipán, Chiclayo, Perú.

2. Medicina Interna, Hospital Santa Rosa, Piura-Perú.

3. Facultad de Medicina, Universidad Santo Toribio de Mogrovejo, Chiclayo, Perú.

4. Universidad San Ignacio de Loyola, Lima, Perú.

a. Médico Internista.

b. Licenciada enfermería. Especialista en salud familiar y comunitaria.

c. Estudiantes de medicina humana.

d. Médico Epidemiólogo.

ORCID:

1. Franco $E$. León-Jiménez 0000-0002-9418-3236

2. Maribel A. Díaz-Vásquez 0000-0002-7950-8805

3. Rosa J. Díaz-Manchay 0000-0002-2333-7963

4. Jimmy F. Malca-Díaz 0000-0002-2532-2124

5. Virgilio E. Failoc-Rojas 0000-0003-2992-9342

\section{CORRESPONDENCE}

Virgilio E. Failoc-Rojas.

Direction: Av La Fontana 501, La Molina, Lima, Perú.

Phone: +51948845837

EMAIL

virgiliofr@gmail.com

CONFLICTS OF INTEREST

Authors declared no conflict of interest.

\section{HOW TO CITE}

León-Jiménez, F., Díaz-Vásquez, M., DíazManchay, R., Malca-Diaz, J., \& Failoc-Rojas, V. COVID-19 y biomasa en Perú: Entre necesidad y riesgo. Revista Del Cuerpo Médico Hospital Nacional Almanzor Aguinaga Asenjo, 2021, $14(1), \quad 110 \quad-\quad 111$. https://doi.org/10.35434/rcmhnaaa.2021.14 1.917

Esta obra está bajo una Licencia Creative Commons Atribución 4.0 Internacional. Versión Impresa: ISSN: 2225-5109 Versión Electrónica: ISSN: 2227-4731 Cross Ref. DOI: 10.35434/rcmhnaaa OJS: https://cmhnaaa.org.pe/ojs 
114465, 10.1016/j.envpol.2020.114465

2. World Health Organization. Household Air Pollution and Health. (2018) Available in: https://archbronconeumol.org/es-asma-epocpacientes-hospitalizados-por-articulo-S0300289620301617.

3. Sharma R, Hossain MM. Household air pollution and COVID-19 risk in India: A potential concern [Internet]. SocArXiv; 2020. Available from: https://osf.io/preprints/socarxiv/4ghde/

4. Instituto Nacional de Estadística e Informática. Hogares en los que cocinan con combustibles contaminantes. Población involucrada y distribución territorial. Lima, abril 2019 Available in: https://www.inei.gob.pe/media/MenuRecursivo/publicaciones_dig itales/Est/Lib1664/libro.pdf

5. Matthew Shupler, James Mwitari, Arthur Gohole, Rachel Anderson de Cuevas, Elisa Puzzolo, Iva Cukic, Emily Nix, Daniel Pope. COVID-19 Lockdown in a Kenyan Informal Settlement: Impacts on Household Energy and Food Security. medRxiv 2020.05.27.20115113; doi: https://doi.org/10.1101/2020.05.27.20115113

6. Diaz de Leon-Martinez L., De la Sierra-De la Vega L., Palacios-Ramirez A., Rodriguez-Aguilar M., Flores-Ramirez R. Critical review of social, environmental and health risk factors in the Mexican indigenous population and their capacity to respond to the COVID-19. Science of The Total Environment. Volume 733, 2020, 139357. https://doi.org/10.1016/j.scitotenv.2020.139357

7. Conticini E, Frediani B, Caro D. Can atmospheric pollution be considered a co-factor in extremely high level of SARS-CoV-2 lethality in Northern Italy? Environ. Pollut. (2020), p. 114465, 10.1016/j.envpol.2020.114465

8. Thakur M., Boudewijns E.A., Babu G.R., van Schayck O.C.P. Biomass use and COVID-19: A novel concern. (2020) Environmental Research, 186, art. no. 109586https://doi.org/10.1016/j.envres.2020.109586

9. Lopez M, Mongilardi N, Checkley W. Enfermedad pulmonar obstructiva crónica por exposición al humo de biomasa. Rev Peru Med Exp Salud Publica. 2014;31(1):94-9.

10. Xiao Wu, Rachel C. Nethery, Benjamin M. Sabath, Danielle Braun, Francesca Dominici. Exposure to air pollution and COVID-19 mortality in the United States: A nationwide cross-sectional study. medRxiv
2020 .
04.05 .20054502 ;
d o i : 